\title{
Oceanographic Factors as the Indicators for Shipyard Industry Development in Kutaraja Fishing Port: A Preliminary Study
}

\author{
Thaib Rizwan ${ }^{1,2}$, Zulkarnain Jalil $^{1,3^{*}}$, Akhyar $^{1,4}$, Husaini $^{1,4}$ \\ 1 Doctoral Program, School of Engineering, Universitas Syiah Kuala (USK), Jl. Syech Abdurrauf No. 7, Darussalam, \\ Banda Aceh, 23111, Indonesia \\ 2 Department of Capture Fisheries, Marine and Fisheries Faculty, Universitas Syiah Kuala (USK), Jl. Syech \\ Abdurrauf No. 7, Darussalam, Banda Aceh, 23111, Indonesia \\ 3 Department of Physics, Mathematics and Natural Science Faculty, Universitas Syiah Kuala (USK), Jl. Syech \\ Abdurrauf No. 7, Darussalam, Banda Aceh, 23111, Indonesia \\ ${ }^{4}$ Mechanical Engineering Department, Faculty of Engineering, Universitas Syiah Kuala (USK), J. Syeh Abdurrauf \\ No. 7, Darussalam, Banda Aceh, 23111, Indonesia \\ * Corresponding author's e-mail: zjalil@unsyiah.ac.id
}

\begin{abstract}
Shipyard development in Kutaraja Fishing Port is important to improve the port performance. The studies related to shipyards are mainly focused on their productivity, facility layout, production capacity, and management and planning. Meanwhile, there are still limited studies related to the influence of oceanographic factors on shipyard development. This research aimed to identify the impact of oceanographic factors on shipyard industry development in Kutaraja fishing port. The research was conducted from December 2020 to March 2021. The data analyzed in this study were tide, wind, current, wave, bathymetry, and sediment composition. The tide, wind, current, and wave data were collected for the last three years from Meteorology, Climatology, and Geophysical Agency. The current moves from two directions, from northeast and northwest, towards the coastal areas around the eastern part of Kutaraja fishing port, closed to the breakwater. The current in the eastern part moves faster than in the western part, and the western part of the sampling area mostly has shallow waters. The highest tide occurs at 12:00 with a water height of -0.3855 meters, and the lowest tide was at 19:00 with a water height of -1.0485 meters. Fine sand dominated the sediment in the sampling area. The result indicates that oceanographic factors are essential to be incorporated as one of the indicators for shipyard development.
\end{abstract}

Keywords: shipyard, fishing port, Kutaraja Ocean, oceanography, sediment.

\section{INTRODUCTION}

Kutaraja Fishing Port is the largest fishing port in Aceh Province (Rizwan et al., 2021). In 2020, fish landing in Kutaraja Fishing Port reached $18,550,924 \mathrm{~kg}$ with operating fishing vessels of 244 units (DKP, 2021). As a largescale port, Kutaraja Fishing Port is required to be able to provide optimum services for operational activities, especially fishing activities from clean water availability, marketing facilities, fish landing facilities, industrial area, to shipyard availability (Rizwan et al., 2021; Sharaan et al., 2017; Rahman et al., 2019).
A shipyard is one of the essential elements in the shipping industry to build and fix ships. Approximately $40 \%$ of the operational cost in shipping organizations is invested in maintenance; thus, making ship fixing the second most crucial aspect (Zaman, 2019). Moreover, the shipyard industry became one of the main drivers of the shipping sector development and increased regional income (Soh et al., 2019). However, the shipyards around the Kutaraja fishing port are still traditional and small-scale.

Soetardjo et al. (2018) argued that various parameters need to be considered before establishing a shipyard. Land geometry is the primary data 
required for shipyard layout design, including the size and shape of each production module location. In shipyard planning, a suitable location is determined based on detailed calculations of various factors, such as water condition, raw material availability, transportation, electricity, consumers/markets, human resources, and environment (Saputra et al., 2017). According to Al Amri (2018), the shipyard layout will improve the material flow efficiency, effective material handling, better production process, enhanced planning system, and work organization flexibility.

Location suitability for shipyard development in a port is determined by oceanographic factors, including current, seawater depth, wind, wave, tide, and sedimentation. Some of the oceanographic aspects, such as current speed, wind, and wave height, are crucial for shipyard development. They can impede the process of exiting and entering the ship into the docking pool. These factors can also cause sedimentation, which can further impact the docking pond silting.

The studies related to shipyard so far were still oriented towards the shipyard productivities (Kyaw et al., 2016), facilities layout (Choi et al., 2016), shipyard production capacity (Lai et al., 2019), and shipyard management and planning (Sukisno et al., 2019). Meanwhile, the studies related to the impact of oceanographic factors on shipyard developments are still limited.
Thus, this research aimed to analyze the impact of oceanographic factors on shipyard industry development in the Kutaraja fishing port.

\section{RESEARCH METHODS}

This research was conducted from December 2020-March 2021 in the Fishing Port of Kutaraja and Marine and Fisheries Faculty Laboratory, Syiah Kuala University. Each sampling point has a vertical distance of $120 \mathrm{~m}$ and horizontal distance of $310 \mathrm{~m}$.

The data analyzed in this research are tide, wind, current, wave, bathymetry, and sediment composition. The Tide, wind, current, and wave data within the study area were collected for the last three years from BMKG (Badan Meteorologi, Klimatologi, dan Geofisikal Meteorology, Climatology, and Geophysical Agency). The water depth samples were collected by emitting echosounder/fishfinder waves to the water substrates. The samples were collected using a grab sampler plugged into the water substrate and transferred to the sampling bag. For each sampling site, $100 \mathrm{gr}$ of samples with three replications was collected. The samples were then dried up and sifted using a dry sieve. The measurement of the sediment particle size was based on the Wentworth scale. The sediment percentage weight was calculated based on each sediment fraction using the equation below:

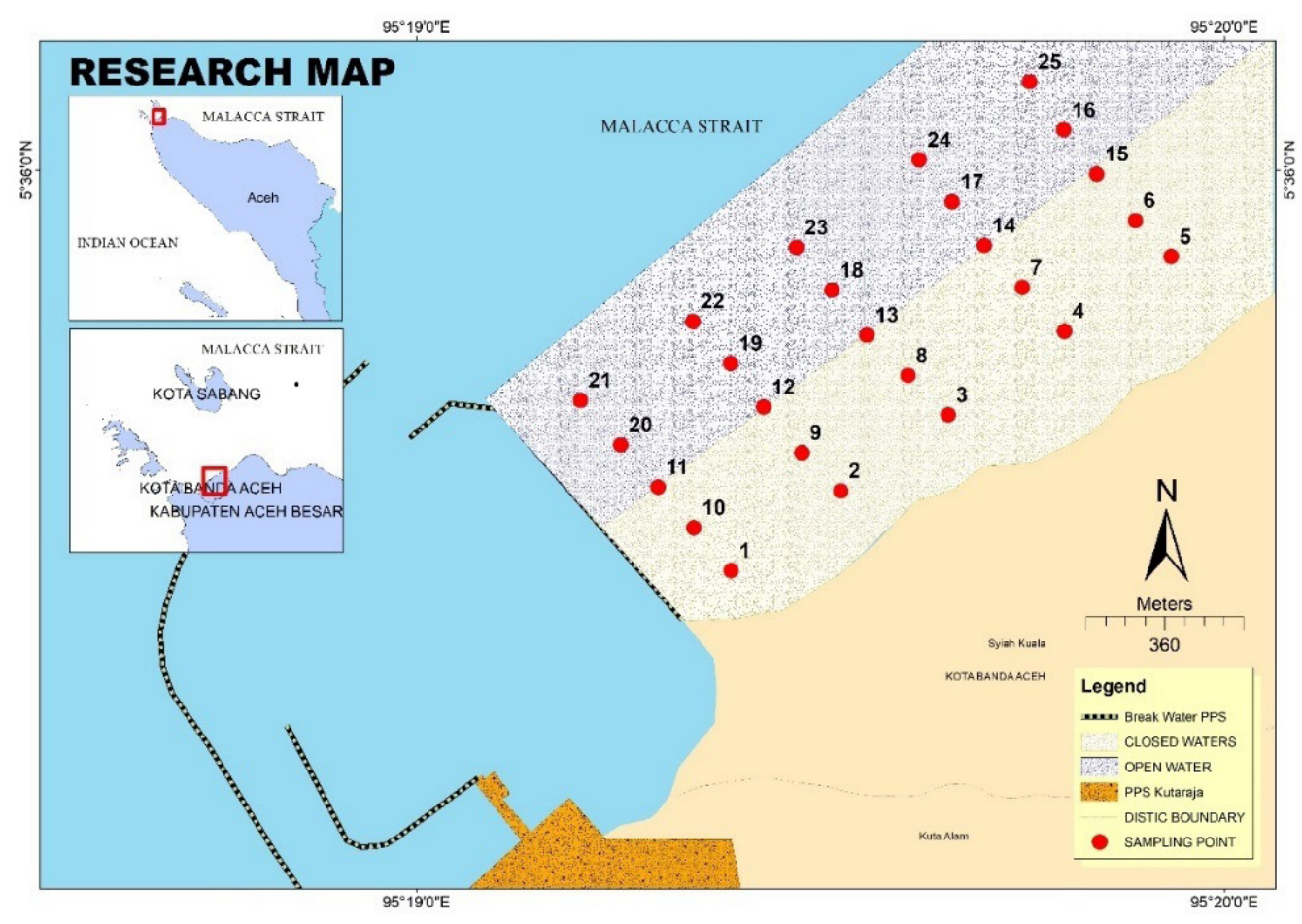

Figure 1. Map of the Research Location 


$$
\text { weight sediment percentage }=\frac{\text { weight fraction }-i}{\text { weight of sample }} \times 100
$$

Further, the tide data was analyzed using the MS Excel software to show the fluctuation over the last three years. Current and bathymetry were visualized using QGIS, while wind data was analyzed with WRP Plot.

\section{RESULT AND DISCUSSION}

\section{Current}

The current pattern in Kutaraja Fishing Port is presented in Figure 2. The current moves from two directions, from northeast and northwest, towards the coastal area around the eastern part of Kutaraja fishing port, located near the breakwater. The current in the easter part has a faster speed than the western part. This condition is perhaps due to the physiological condition of the area, which is flanked by two large rivers in the eastern and western parts. Hence, those two rivers influence the current movement. Current speeds in the areas with red-colored contours have strong currents with speeds between 0.14 $\mathrm{m} / \mathrm{s}$ to $0.23 \mathrm{~m} / \mathrm{s}$. Reis et al. (2011) revealed that a shipyard with a complex structure could reduce current circulation around the shipyard, creating an anoxic condition and eutrophication in the water column and water sediment if not appropriately addressed.

\section{Bathymetry}

The research showed that sea depth ranged between 1 meter to 9 meters and deeper towards the offshore. The light blue colors on the bathymetry map show shallows waters, while the dark blue colors show deeper waters (approximately 9 meters). Deeper waters have a greater tidal current than shallow waters due to the smaller friction between the water bodies layer near the surface and the surface layer compared with water substrate (Thiebeut dan Sentchev, 2017). The shallowest waters are located near the breakwater of Kutaraja Fishing Port due to the current pattern that tends to end in that area. The current from the river carries sediment and gradually will accumulate, causing silting of the waters. Azevedo et al. (2016) argued that the watershed area and precipitation influenced the amount of sediment carried by the river. Ohl et al. (2020) explained that depth is an essential factor that needs to be considered in shipyard development. For example, a floating dock requires a certain depth to support the dock and maximum lifting capacities. In most deep waters,

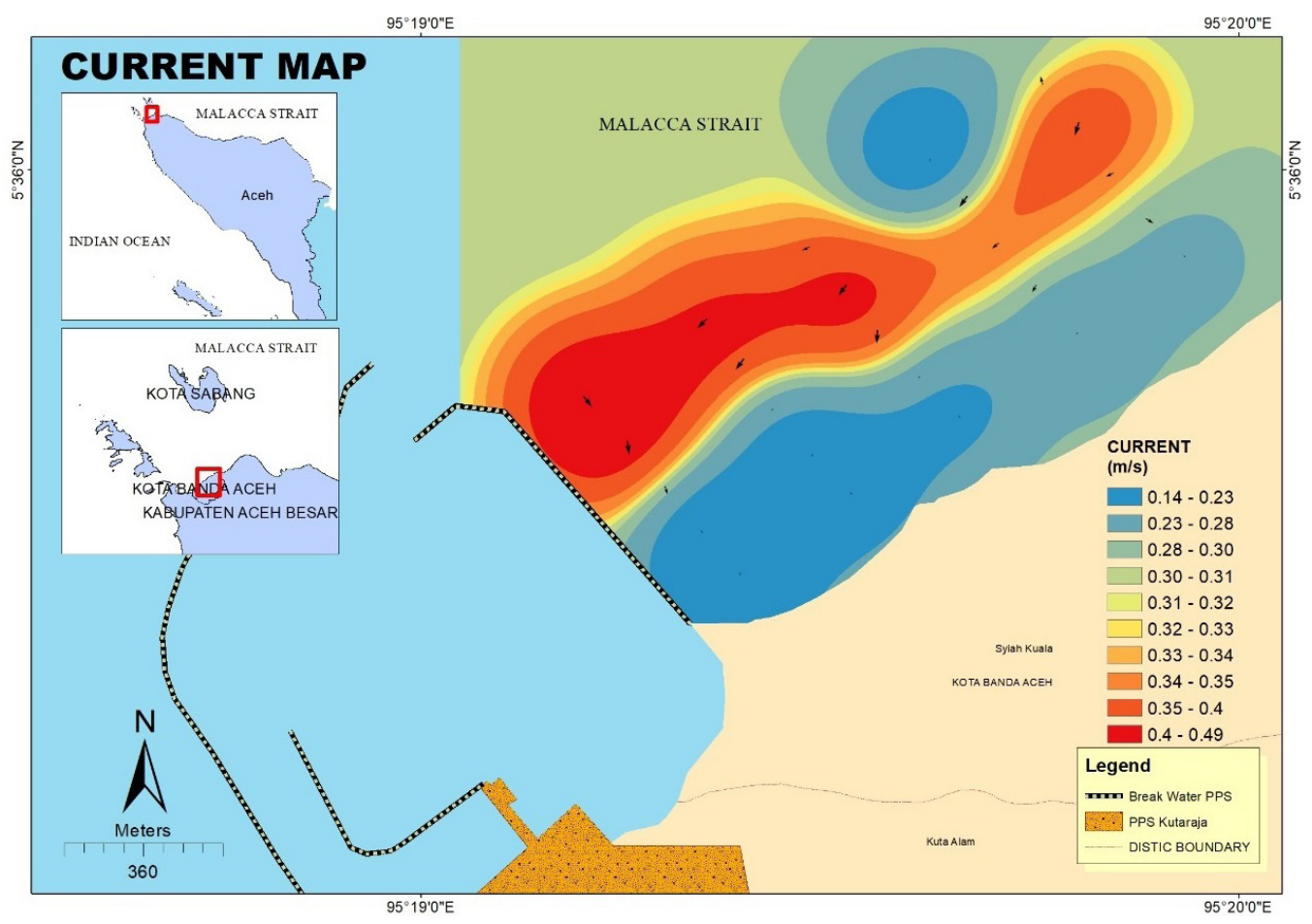

Figure 2. The current pattern in the research location 


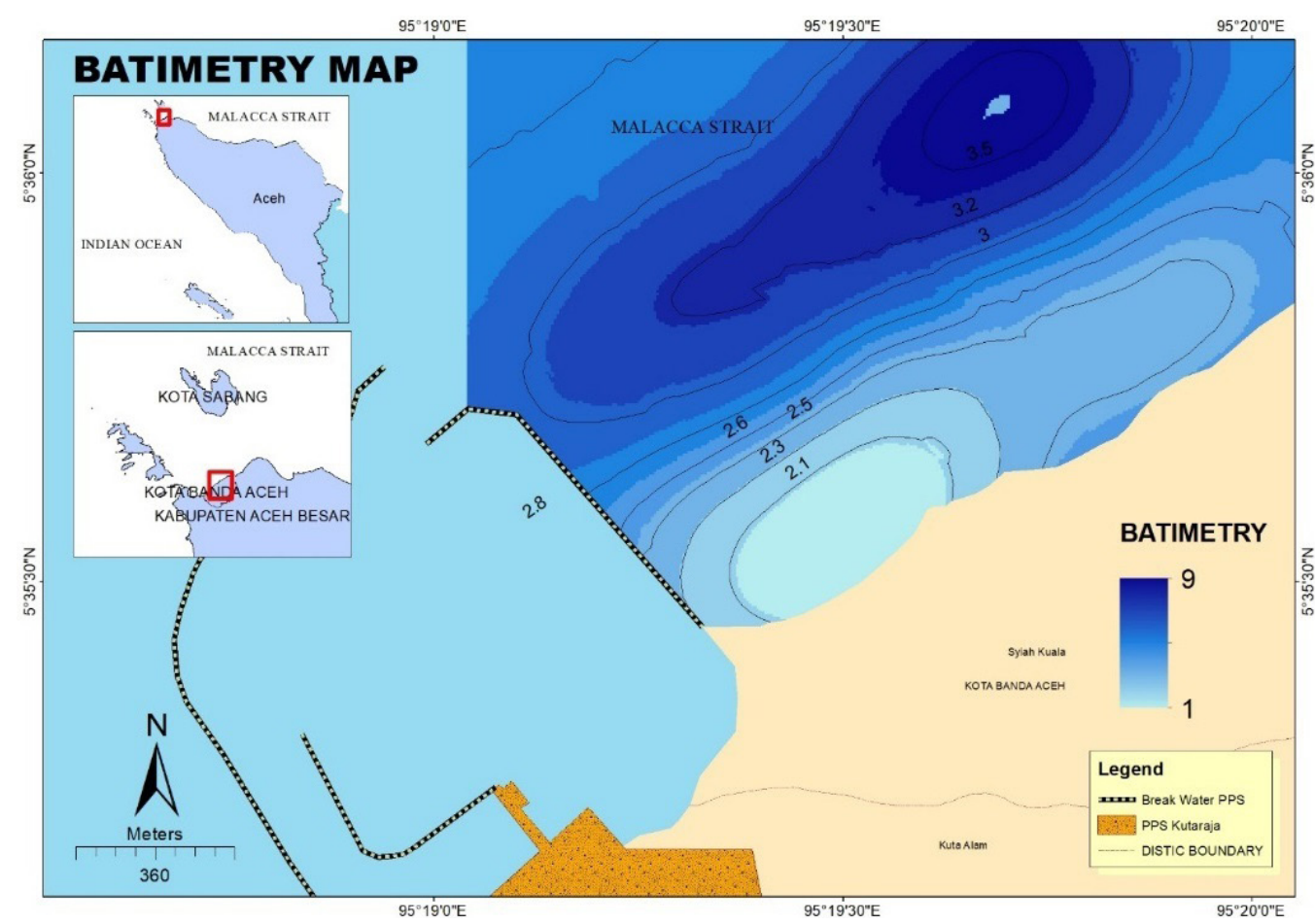

Figure 3. Bathymetry measurement

floating dock mobilization will cost less than the civil and structural works related to graving docks.

\section{Wave}

The $\mathrm{x}$-axis represents the record time-series data of water height for the last three years per hour, while the y axis represents the recorded wave height (Figure 5). On the basis of the figure above, wave height in the study area ranged between 0.07 $\mathrm{m}$ to $1.7 \mathrm{~m}$ and a period of 21.5 seconds to 22.31 seconds. The highest average wave occurred in the east monsoon on 16 January 2019, with a value ranging between $1.2 \mathrm{~m}-1.7 \mathrm{~m}$. The lowest average wave occurred in the transition season on 29 September 2019, with a value of $0.07 \mathrm{~m}$.

\section{Wind}

Wind highly influences the wave height, where the stronger the wind, the higher the wave height will be. The wind that moves towards the coastal area has

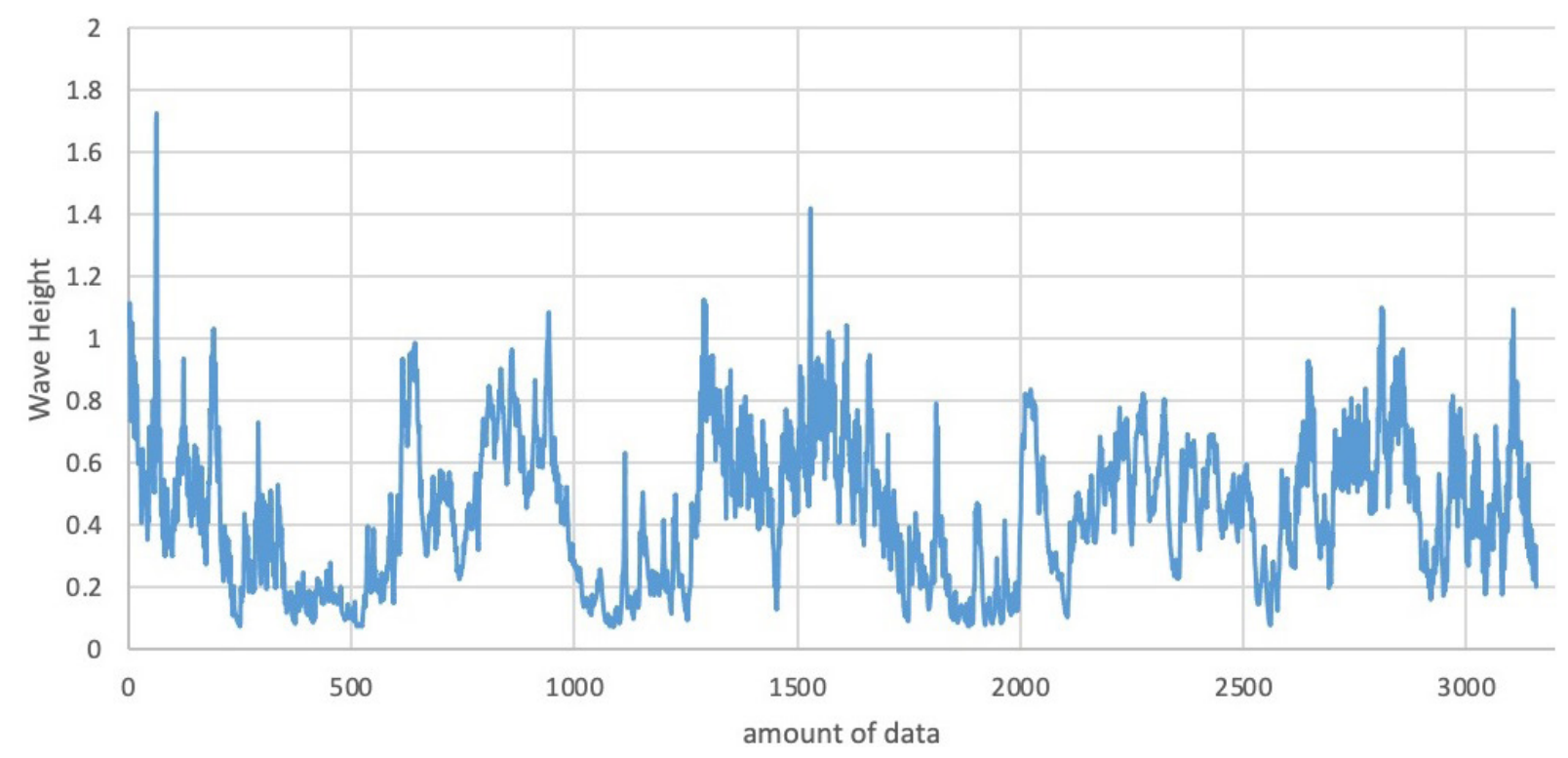

Figure 4. Wave measurement 
high energy and will create a large wave; on the other hand, the wind that moves towards the high seas or oceans has low energy, thus creating small waves. The figure above (see Figure 6) shows the relationship between wind speed classification ( $\mathrm{x}$-axis) and the number of wind speeds recorded (y-axis). The result varies from December 2019 to February 2020, with the most recorded wind speed classification is $3.00-4.00 \mathrm{~m} / \mathrm{s}$ with $29.6 \%$, and the lowest is clams classification with $1.1 \%$. The wind speed recorded between March and May 2020 also shows variation. The highest is $1.00-2.00 \mathrm{~m} / \mathrm{s}$ classification with $27.7 \%$, while the lowest is $\geq 6.00 \mathrm{~m} / \mathrm{s}$ classification with $1.3 \% .1 .00-2.00 \mathrm{~m} / \mathrm{s}$ classification was also the highest between June and August 2020 with 27.7\%, and the lowest is $\geq 6.00 \mathrm{~m} / \mathrm{s}$ with $1.9 \%$.

The highest wind speed recorded between September to November 2020 is $3.00-4.00 \mathrm{~m} / \mathrm{s}$ classification with $23.9 \%$, and the lowest is $\geq 6.00$ $\mathrm{m} / \mathrm{s}$ with $2.5 \%$. Wind speed and wave parameters (wave height and wave speed) show the sediment exponential distribution pattern, while wind and current speed have a similar sediment distribution. Increasing the wind speed on the water surface will increase the sediment concentration and size in the water column (ShaSha et al., 2015).
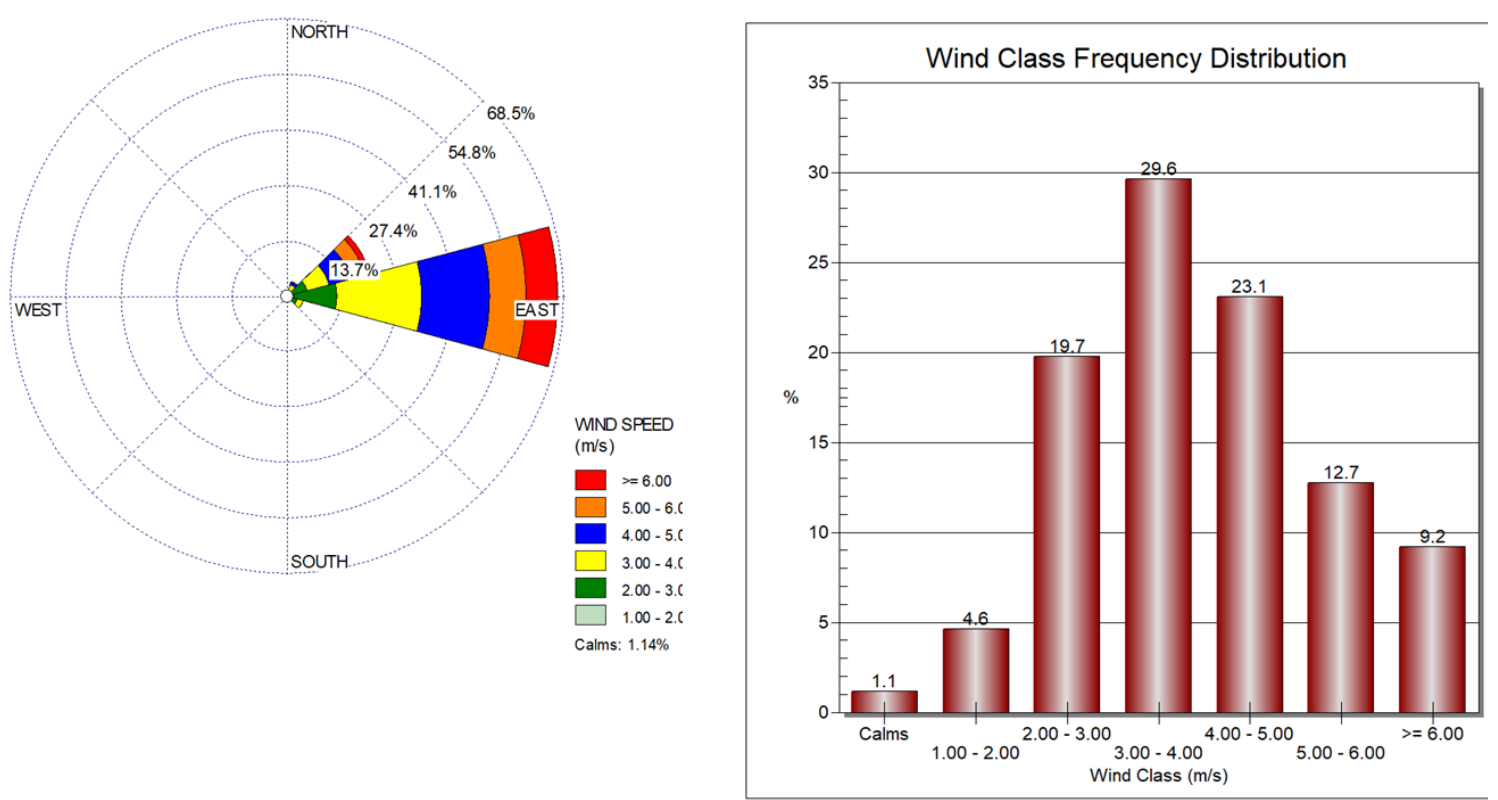

Figure 5. The wind speed recorded between December 2019 and February 2020
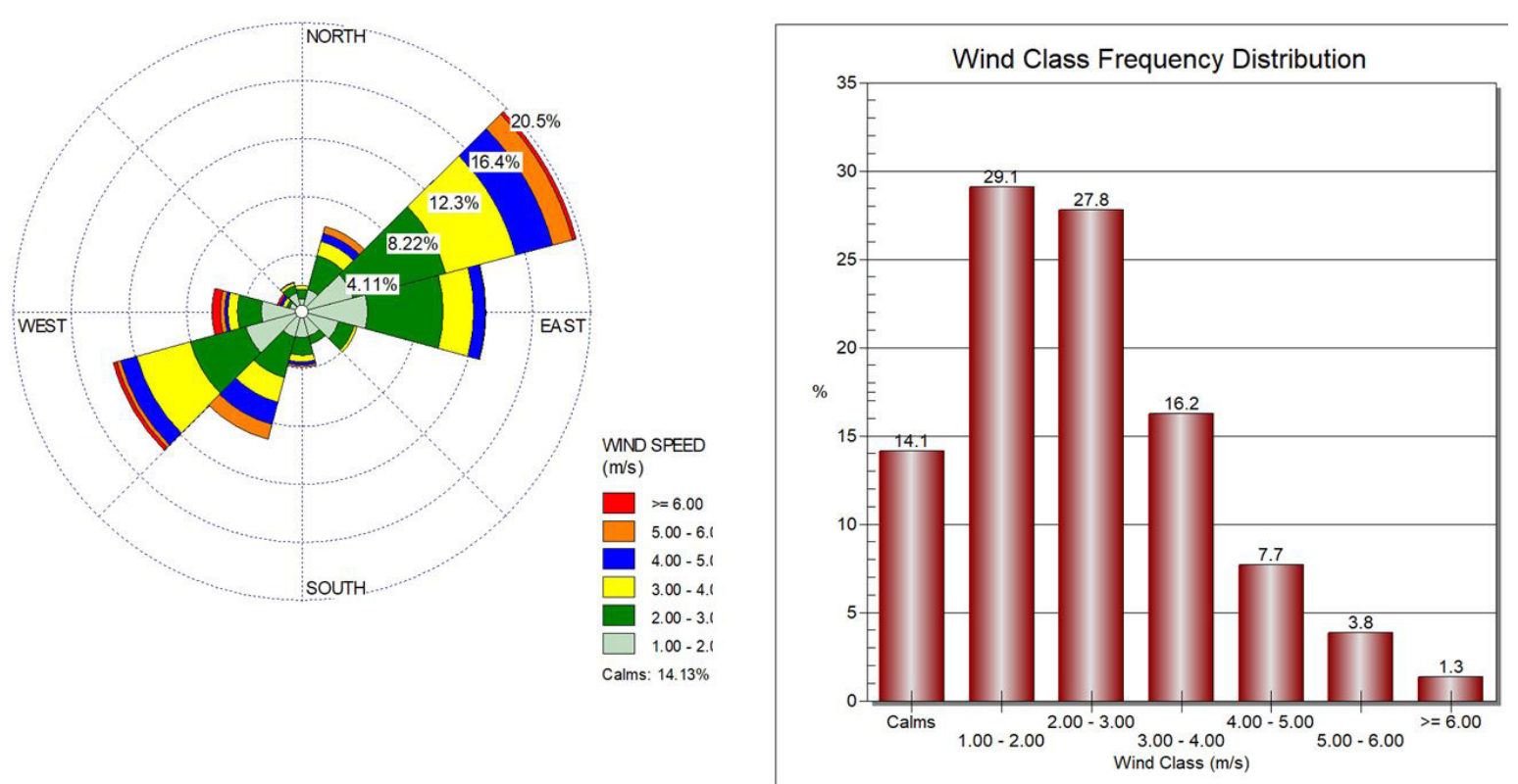

Figure 6. The wind speed recorded between March and May 2020 

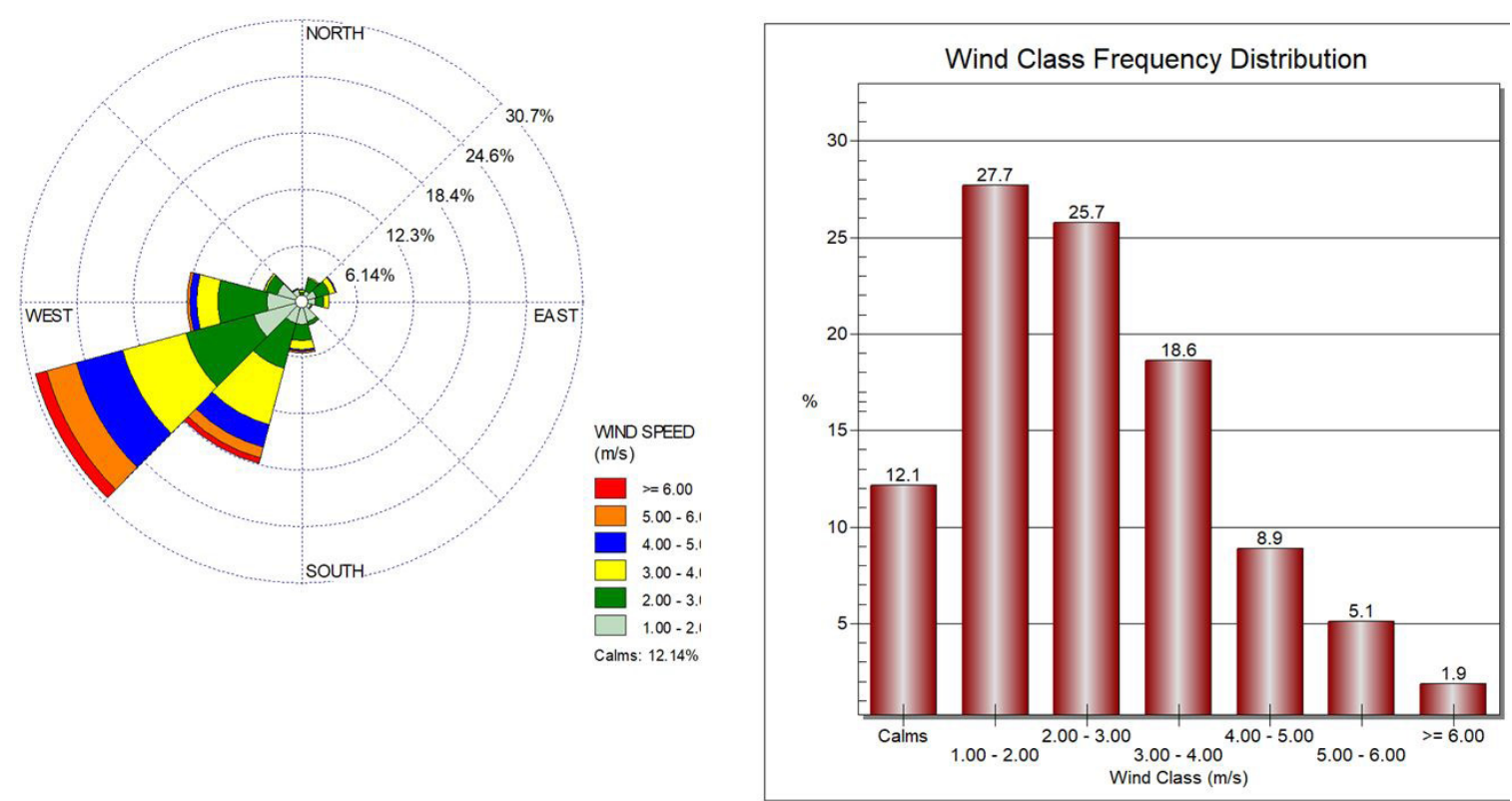

Figure 7. The wind speed recorded between June and August 2020
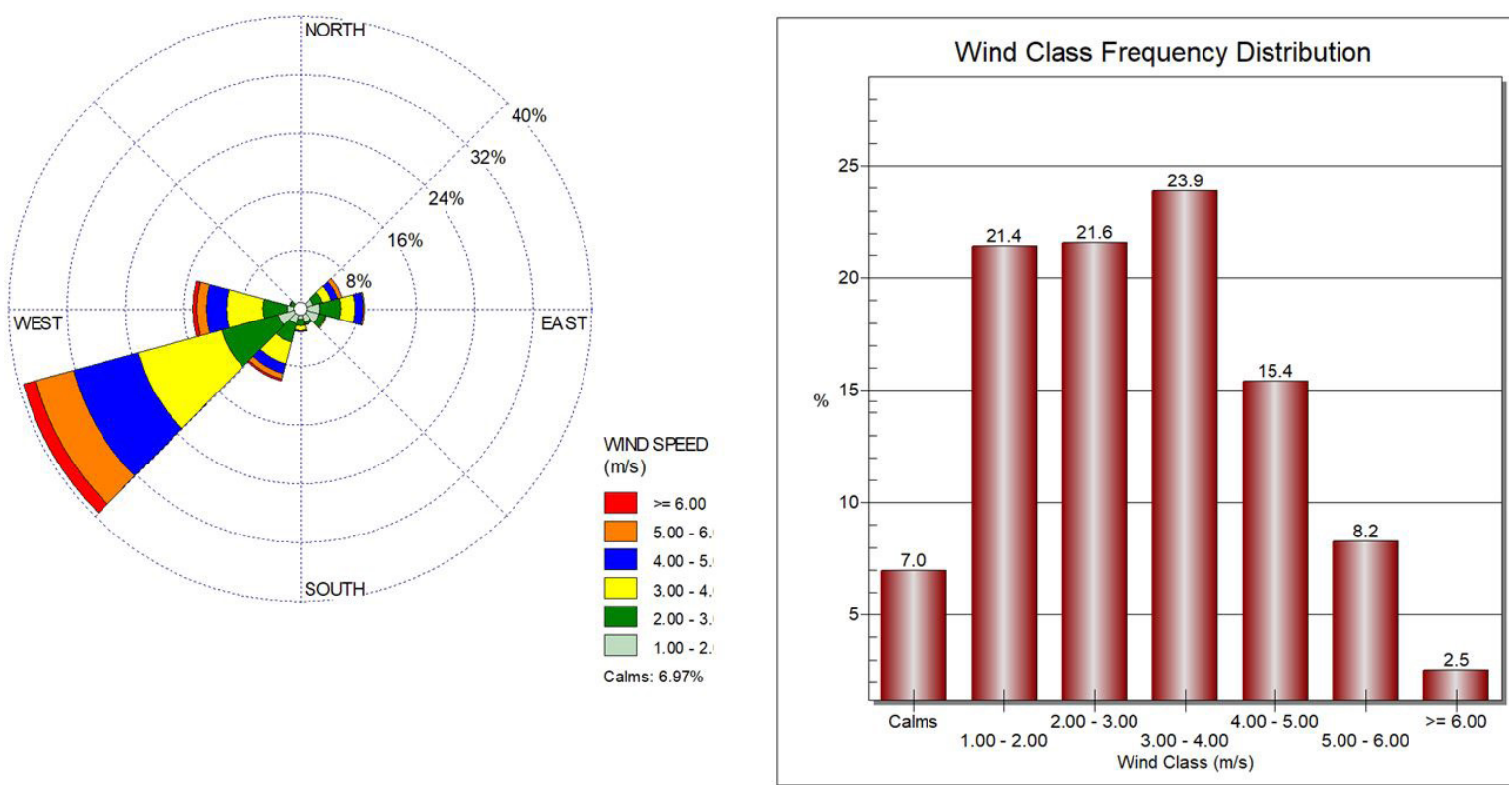

Figure 8. The wind speed recorded between September - November 2020

\section{Tide}

Tidal waves are determined by the force of attraction between two forces in the ocean, centrifugal forces caused by the Earth's rotation on its axis and the Moon's gravitational force. The Moon, Earth, and Sun position creates fluctuating tidal waves from the surface water level (Katu et al., 2020). Water circulation influenced by the tidal current carries sediment material in the waters; thus, tidal current patterns will determine its sediment transport pattern.

The tide condition in the study area on 24 January 2021 can be seen in the figure above, where the highest tide was at 12:00 PM with a water height of -0.3855 meter, and the lowest was at 19:00 with a water height of -1.0485 meter. At a particular condition, the forces produced by the tides will interact with the bathymetry to form an internal wave. This force will influence the periodicity of the tide to disperse far away from its source (Poulain and Centurioni, 2015).

The figure above presents the recorded tidal data over the past three years (24 January 2019 to 24 February 2021), where the highest and the lowest tide occurred on 24 January 
Sea Level at January 24th, 2021

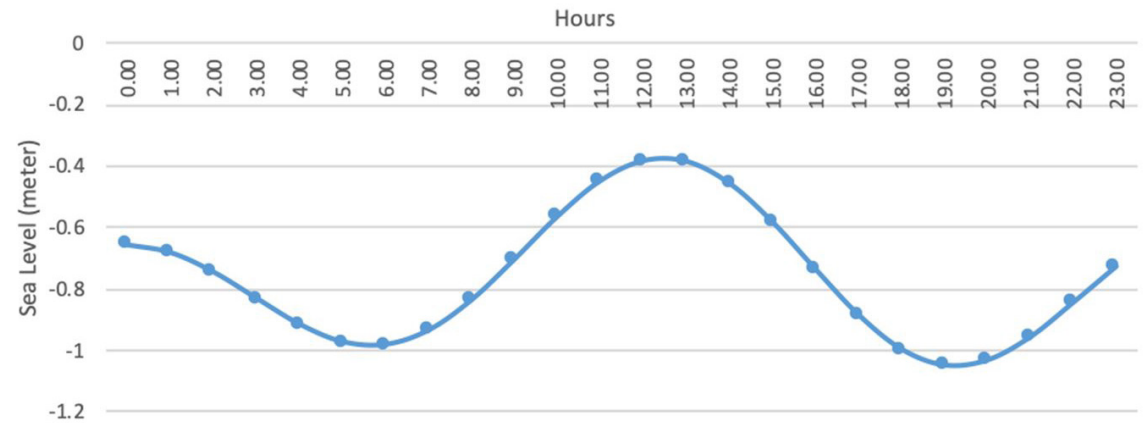

Figure 9. Tidal measurement

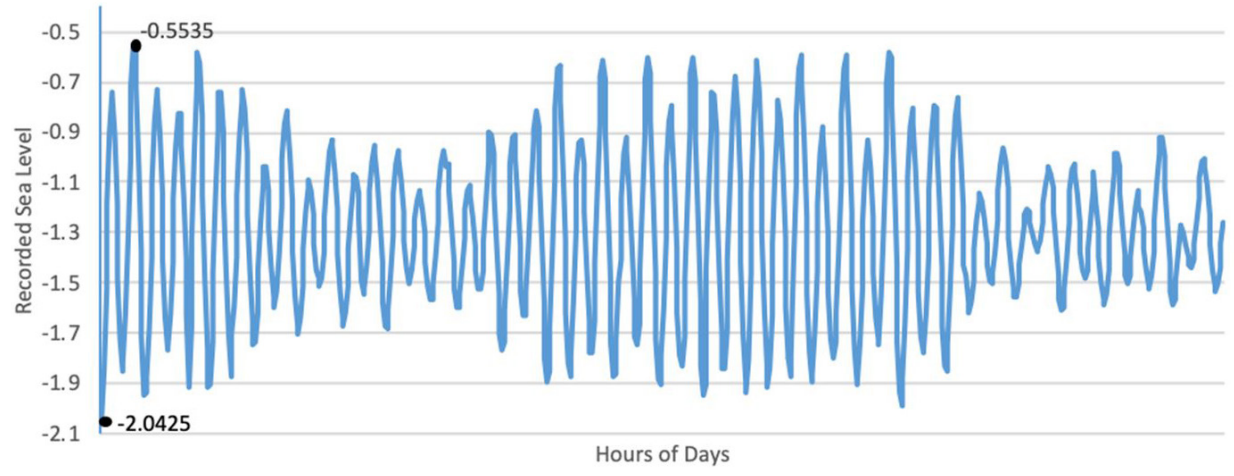

Figure 10. Tidal measurement

2019. The highest tide occurred at 17:00 (water height of -0.5535 meter), and the lowest tide at 00:00 (water height of -2.0425 meter). The tidal current in the shallow and deep-sea are essential for heat and momentum mixing. Tidal energy is mainly absorbed by the fraction on the seafloor due to the sea topography and thus creates internal waves (Poulain and Centurioni, 2015).

\section{Sediment}

This study showed that the Kutaraja Fishing Port water consists of three major sediments based on the Wentworth scale. The three types are fine sand (particle size of $1 / 8-1 / 4 \mathrm{~mm}$ ), very fine sand (particle size of 1/16 - 1/8 mm), coarse sand (particle size of $1 / 2-1 \mathrm{~mm}$ ), and medium sand (particle size of $1 / 4-1 / 2 \mathrm{~mm}$ ). The sediment

Table 1. Sediment Classification

\begin{tabular}{|c|c|c|c|c|}
\hline \multicolumn{5}{|c|}{ Station/ average particle size $(\mathrm{Mz}) /$ Sediment Classification } \\
\hline $\begin{array}{c}1 \\
0.16 \mathrm{~mm} \\
\text { (Fine Sand) }\end{array}$ & $\begin{array}{c}2 \\
0.18 \mathrm{~mm} \\
\text { (Fine Sand) }\end{array}$ & $\begin{array}{c}3 \\
0.18 \mathrm{~mm} \\
\text { (Fine Sand) }\end{array}$ & $\begin{array}{c}4 \\
0.13 \mathrm{~mm} \\
\text { (Fine Sand) }\end{array}$ & $\begin{array}{c}5 \\
0.12 \mathrm{~mm} \\
\text { (Fine Sand) }\end{array}$ \\
\hline $\begin{array}{c}6 \\
0.09 \mathrm{~mm} \\
\text { (Very Fine Sand) }\end{array}$ & $\begin{array}{c}7 \\
0.58 \mathrm{~mm} \\
\text { (Coarse sand) }\end{array}$ & $\begin{array}{c}8 \\
0.15 \mathrm{~mm} \\
\text { (Fine Sand) }\end{array}$ & $\begin{array}{c}9 \\
0.14 \mathrm{~mm} \\
\text { (Fine Sand) }\end{array}$ & $\begin{array}{c}10 \\
0.58 \mathrm{~mm} \\
\text { (Coarse sand) }\end{array}$ \\
\hline $\begin{array}{c}11 \\
0.5 \mathrm{~mm} \\
\text { (Coarse sand) }\end{array}$ & $\begin{array}{c}12 \\
0.14 \mathrm{~mm} \\
\text { (Fine Sand) }\end{array}$ & $\begin{array}{c}13 \\
0.2 \\
\text { (Medium sand) }\end{array}$ & $\begin{array}{c}14 \\
0.17 \mathrm{~mm} \\
\text { (Fine Sand) }\end{array}$ & $\begin{array}{c}15 \\
0.18 \mathrm{~mm} \\
\text { (Fine Sand) }\end{array}$ \\
\hline $\begin{array}{c}16 \\
0.19 \mathrm{~mm} \\
\text { (Fine Sand) }\end{array}$ & $\begin{array}{c}17 \\
0.08 \mathrm{~mm} \\
\text { (Very Fine Sand) }\end{array}$ & $\begin{array}{c}18 \\
0.12 \\
\text { (Fine Sand) }\end{array}$ & $\begin{array}{c}19 \\
0.11 \mathrm{~mm} \\
\text { (Fine Sand) }\end{array}$ & $\begin{array}{c}20 \\
0.59 \\
\text { (Coarse sand) }\end{array}$ \\
\hline $\begin{array}{c}21 \\
0.16 \mathrm{~mm} \\
\text { (Fine Sand) }\end{array}$ & $\begin{array}{c}22 \\
0.18 \mathrm{~mm} \\
\text { (Fine Sand) }\end{array}$ & $\begin{array}{c}23 \\
0.66 \mathrm{~mm} \\
\text { (Coarse sand) }\end{array}$ & $\begin{array}{c}24 \\
0.28 \mathrm{~mm} \\
\text { (Fine Sand) }\end{array}$ & $\begin{array}{c}25 \\
0.14 \mathrm{~mm} \\
\text { (Fine Sand) }\end{array}$ \\
\hline
\end{tabular}


with the particle size of fine sand was found in 17 sampling sites, very fine sand was found in 2 sampling sites, medium sand was found only in one sampling site, and coarse sand was found in 5 sampling sites (Table 1). The two rivers influence the sediment particle sizes in the eastern and western areas. According to Golabi et al. (2018), the rivers have different characteristics based on the land use, size of the subwatershed, river length, and river geological contour. It is assumed that the coastal areas are dominated by sand sediment due to the resistance of the sand to the current movement; thus, sands are not carried away by the speed and current direction (Jalil et al., 2019; Muhammad et al., 2019; Maulinda et al., 2019)

\section{Impact of oceanographic factors on the shipyard location development in Kutaraja Fishing Port}

The area for shipyard development in Kutaraja Fishing Port can be categorized as suitable for shipyard development. This result is based on the water oceanographic factors in the area that are ideal for shipyard development. Stable current with good depth, stable wave height and wind speed, and the highest tide and sediment patterns are suitable for the shipyard industry development in the Kutaraja fishing port, Aceh.

\section{CONCLUSIONS}

The study on several oceanographic parameters around Kutaraja Fishing Port showed that the current moves from two directions, northeast and northwest, towards the coasts in the eastern area - near the breakwater. The current in the easter location is stronger than in the west area. Furthermore, the western area is dominated by shallow water. The highest tide was observed at 12:00 with (0.3855 meters) and the lowest at 19:00 (-1.0485 meters). Most of the sampling area has a sediment particle size of the fine sand. The result indicates that oceanographic factors are essential to becoming one of the indicators in shipyard development.

\section{Acknowledgements}

Authors greatly thank to Muchlis, S.kel, (Chemistry Lab., FKP USK), Ayana Rizki, S.Pi, Salsabila, S.Pi, Selli Anggi Pratiwi, S.Pi and Nanda Rizki Purnama. M.Si (Navigation Lab, PSP
USK) for collecting data. Authors acknowledge also PSDKP Aceh for their contribution in the sampling process. ZJ gratefully special acknowledge the support of the Kementrian Pendidikan, Kebudayaan, Riset dan Teknologi (Kemendikbudristek) through PKKM Research Grant Year of 2021.

\section{REFERENCES}

1. AlAmri F.S. 2018. Study of technologies and processes in shipbuilding industry. International Journal of Multidisciplinary and Current Research, 6, 101-102.

2. Azevedo J.W.D.J., de Casto A.C.L., dos Santos M.F.V. 2016. Siltation rate and main anthropic impact on sedimentation of the sao luis tidal inlet state of maranho, Brazil. Brazilian journal of oseanography, 64(1), 9-18.

3. Chao S.L. 2020. Comparing The Productivity Of Major Shipyards In China, South Korea, And Japan An Application Of A Metafrontier Framework. Maritime Business Review, 5(2), 193-194.

4. Golabi M.H., Manibusan S., Righetti T., Okano D., Iyekar C. 2018. Using vetiver grass technology for mittigating sediment loads in the talakhaya wetershed ateas in rota, CNMI. International soil and water conservation research, 6, 194-201.

5. Jalil Z., Rahwanto A., Mulana F., Handoko E. 2019. Synthesis of nano-hematite $\left(\mathrm{Fe}_{2} \mathrm{O}_{3}\right)$ extracted from natural iron ore prepared by mechanical alloying method, AIP Conference Proceedings, 2151, 020041.

6. Katu U., Zubair A., Sahbuddin A.K. 2020. Tidal sea water measurement monitoring system. International journal of civil engineering anf technology (IJCIET), 11(2), 79-87.

7. Kholis M.N., Ikhsan S.A., Wulandari U. 2020. Aktivitas dan jaringan kerja pembuatan kapal perikanan 5 gt di galangan kapal ud. Oliong kabupaten rokan hilir provinsi riau. Aurelia journal, 1(2), 61-70.

8. Lestari F.R., Octavian A., Harsono G. 2019. Sistem informasi geografis (sig) untuk rancangan dock pt pal sebagai obyek vital nasional dalam rangka pengembangan wilayah industri pertahanan di teluk semangka provinsi lampung. Julnal teknologi penginderaan, 1(2), 127-150.

9. Li J., Sun M., Han D., Wu X., Yang B., Mao X., Zhou Q. 2018. A Governance Platform for MultiProject Management in Shipyard. Computers and Engineering, 120, 179-180.

10. Muhammad M., Fatmaliana A., Jalil Z. 2019. Study of hematite mineral $\left(\mathrm{Fe}_{2} \mathrm{O}_{3}\right)$ extracted from natural iron ore prepared by co-precipitation method, IOP Conf. Series: Earth and Environmental Science, 348, 012135.

11. Maulinda, Zein I., Jalil Z. 2019. Identification of Magnetite Material $\left(\mathrm{Fe}_{3} \mathrm{O}_{4}\right)$ Based on Natural 
Materials as Catalyst for Industrial Raw Material Application, IOP Conf. Series: Journal of Physics: Conf. Series, 1232, 012054.

12. Poulain P., Marrie, Centurioni L. 2015. Direct measurements of world ocean tidal current with surface drifters. Journal of geophysical research: oceans, 120(10), 6986-7003.

13. Pratama P., Fadillah A. 2019. Study on development of shipyard type for supporting pioneer ship in Indonesia. The First Maluku International Conference on Marine Science and Technology, 339, 5-8.

14. Rahmah A., Rizayani M., Chalilluddin. 2018. Pengaruh kualitas Pelabuhan Perikanan Samudera Lampulo terhadap kelancaran operasional penangkapan ikan. Jurnal Depik. ISSN: 2502-6194.

15. Rahman A. \& Mahreda E.S. 2019. Marketing channels of marine fish in Banjarmasin fishing port, Indonesia. International Journal of Fisheries and Aquatic Research, 4(3), 15-22.

16. Rizwan T., Kandi O., Jalil Z., Setiawan I., Maulana R., Ranti D.M.V., Chaliluddin M.A. 2021. The analysis of clean water need for fishing activities in Kutaraja Fishing Port, Aceh Indonesia. Australian Journal of Maritime \& Ocean Affairs, 13(1), 1-11.

17. Saputra B., Mulyanto I.P., Amiruddin W. 2017. Studi Perancangan Galangan Kapal untuk Pembangunan Kapal Baru dan Perbaikan di Area Pelabuhan Pekalongan. Jurnal Teknik Perkapalan, 5(2), 353-366.
18. ShaSha Zheng W., PeiFang W., Chao H. Jun. 2015. Sediment resuspension under action of wind i Taihu Lake, China. Inernational Journal of Sediment Research, 30(1), 48-62.

19. Sharaan M., Negm A., Iskander M., Nadaoka K. 2017. Questionnaire-based assessment of Mediterranean fishing ports, Nile Delta, Egypt. Marine Policy, 81, 98-108.

20. Soetardjo M., Wardhana E.M., Bisri A. 2018. Perencanaan Awal Tata Letak Galangan Kapal Di Daerah Kawasan Lahan Terbuka. Applied Technology and Computing Science Journal, 1(1), 54-58.

21. Soh M.C., Shamsuddin S.M., Hasan S. 2019. ANew Framework for Dynamical Resources Planning System in Shipbuilding Industri. Int. J. Advance Soft Compu, 11(1), 146-148.

22. Thiebeut M., Santchev A. 2017. Asymmetry of tidal current off the W. Brittany coast and assessment of tidal energy resource around the Ushant island. Renewable Energy, (105) 2017, 735-747.

23. Widiyastuti A.E., Aprianingsih A. 2019. Proposed Marketing Strategy of PT. Pelabuhan Indonesia III (Persero) Property the Cas of Tegal Port. Journal of International Conference Proceedings, 5.

24. Yasin A.M., Sukiyah E., Isnaniwardhani V. 2016. Grain size analysis of quartenay sediment from kendari basin, Indonesia. International journal of science and research, 5(11), 1748-1751.

25. Zaman M.B., Siswantoro N., Nandiansyah R.R. 2019. Risk Assessment In Ship Repair Scheduling. Intern. 